JOURNAL OF SECURITY AND SUSTAINABILITY ISSUES

ISSN 2029-7017 print/ISSN 2029-7025 online

2019 September Volume 9 Number 1

http://doi.org/10.9770/jssi.2019.9.1(21)

Scopus

\title{
HUMAN RESOURCES MANAGEMENT FACETS: ROLE OF ORGANIZATIONAL COMMITMENT
}

\author{
Slamet Widodo ${ }^{1}$, Marlina Widiyanti² ${ }^{2}$ Tetra Hidayati ${ }^{3}$, Wiyadi $^{4}$, Nelson Situmorang ${ }^{5}$ \\ ${ }^{1}$ Department of Management, Faculty of Economics and Business, Bengkulu University Indonesia \\ ${ }^{2}$ Department of Management, Faculty of Economics, Universitas Sriwijaya Palembang, Indonesia \\ ${ }^{3}$ Department of Management, Faculty of Economic and Business, University of Mulawarman Samarinda, Indonesia \\ ${ }^{4}$ Master of Management study program, Graduate School, Universitas Muhammadiyah Surakart, Indonesia \\ ${ }^{5}$ Department of Management, Faculty of Economic and Business, Universitas Bengkul, Indonesia \\ E-mails:'swidodo@unib.ac.id; ${ }^{2}$ marlinawidiyanti68@yahoo.co.id; ${ }^{3}$ hidayati.tetra@yahoo.com; \\ 4wiyadi@ums.ac.id; ${ }^{5}$ nelsonsitumorang99@gmail.com
}

Received 14 January 2019; accepted 25 June 2019; published 30 September 2019

\begin{abstract}
The prime objective of the current study is to explore the nexus between job involvement, turnover, and organizational commitment. Meanwhile, the study has examined the mediating role of organizational commitment in the relationship between job involvement and turnover. The study broached an argument that in the era of globalization, it has been regarded to be a key issue to deal with employee turnover for any business organization. To date, agreement on how to practice this concept has not yet been resolved. Employing the survey-based methodology, the SEM-PLS technique is used to test the hypothesized relationships. So, the current study has used SEM-PLS as a statistical tool to answer the research questions raised in this study and research objectives envisaged in the current study. The data is collected from the managers of the manufacturing firms in Indonesia. The findings of the study have provided support to the theoretical foundation and the proposed hypothesis of the current study. The current study will be helpful for policymakers and practitioners in understanding the issues related to job involvement, turnover, and organizational commitment. In author knowledge, this is among very few pioneering studies on this issue.
\end{abstract}

Keywords: job involvement; turnover; organizational commitment; Indonesia

Reference to this paper should be made as follows: Widodo, S.; Widiyanti, M.; Hidayati, T.; Wiyadi, Situmorang, N. 2019. Human resources management facets: role of organizational commitment, Journal of Security and Sustainability Issues 9(1): 281-293. http://doi.org/10.9770/jssi.2019.9.1(21)

JEL Classifications: J28, J63

\section{Introduction}

Organizations have shifted focus from tangible to intangible sources to built and sustain competitive advantage so they can survive in the current era of a competitive market. The intellectual capital of the organization is reflected through competencies, capabilities and knowledge-based resources. These factors are defining the knowledge-based economy on an increasing basis. Thus, the main focus of organizations now a day is building the human capital, information system resources, knowledge management and intellectuals. It is important to realize their main role as the critical force, which makes the organization successful and help in sustaining their competitive advantage (Dahiyat, 2015).

In the current era of globalization, employee turnover is the basic issue of the number of organizations. Researchers reported that employee turnover is a serious issue for firms. Organizations are burdened by providing good pay along with other benefits, and good working environment, which is important to fulfill the needs of 
the employee (Yin-Fah, Foon, Chee-Leong, \& Osman, 2010; Bernardi, 2019; Lorincová et al., 2019).

It is the desire of every business firm that turnover of an employee is reduced, and its productivity is increased. As a result, profitability is increased as well. Reducing the turnover of the employees is the obligation of the organization. When organization have to hire the new employee, they have to bear the direct cost including recruitment, selection, orientation, workshop and training of the newly hired employee. There are indirect costs associated like the collapse of social capital stress among the workers, reduction in self-confidence of employees and spending on the newly hired employee. Additionally, it becomes very difficult for an organization to achieve its goals in the presence of employee turnover. In-fact employee turnover is the major concern for the organizations, and they are looking to adopt the strategies by which they can retain the employees (Al Mamun \& Hasan, 2017).

It is the permanent challenge for the organizations to retain the professionals for a larger period of time. An employee leaves the organization for a number of reasons. Two of the major reasons to leave the organizations are "job involvement" and "organizational commitment" (Alshammari, Qaied, Al-Mawali, \& Matalqa, 2016; Bonds, 2017; Wynen, Van Dooren, Mattijs, \& Deschamps, 2019; Yücel, 2012). Therefore, in the current study, we are discussing these two factors in order to know that two of these factors might be emphasized. It is critical for organizations and management to understand different strategies required to persuade their employees, so they continue to work for the organization. The main concern of the employers should be to produce committed employees so they can reduce absenteeism and turnover, which in turn will increase the performance and revenue of the firm (Ahmed \& Nawaz, 2015).

One of the major factors that helped organizations to improve their productivity in the recent past is the organizational commitment of employees. Every employee is part of the organization working in that organization. The commitment of every employee varies who work in the organization. One of the major factors of employee commitment is the way employee see the organization and the differences among them and other employees that make them separate from others. The committed employee is very important for the organization. The organization use a number of resources to find the correct person for the job. At this stage, it becomes very important for the firm to retain that employee for a longer period of time. In this process, commitment comes into play, which is an emotional response which can be measured by the behavior, attitude and beliefs of the people, which varies from high to low (Anttila, 2015:Mahmood et al., 2016; Hussain, Abidin, Ali, \& Kamarudin, 2018).

For this reason. Employers try to develop the workforce which is committed through the adoption of strategies that are best for retention of employees. The positive attitude of the organization is the one example which gives organization ability to create satisfaction and job involvement among the employees. Additionally, when the workforce is committed, involved and motivated in their work, it is called the special asset for the organization and plays a critical role in the success of the firm and reducing the rate of turnover as well (Abdallah, Obeidat, Aqqad, Al Janini, \& Dahiyat, 2017; Orji et al, 2018; Perera et al, 2018; Pratama \& Meutia, 2018).

Researchers have defined job involvement as the importance of working between the people and values of goodness. Job involvement is the subjective condition which makes employees devoted toward their job. As a result of job involvement and job, commitment, employees spend energy to achieve personal and organizational goal. When there are commitment and involvement of employees towards their job, workers enjoy the work and tasks assigned to them. Job involvement reduces the desire to leave the job and increase the participation, voluntary actions, emotional attachments, organizational citizenship behavior, organizational commitment and job satisfaction among the employees of the organization (Rahati, Sotudeh-Arani, Adib-Hajbaghery, \& Rostami, 2015).

Job involvement of employee results in the presence of employee timely at work, employees feeling of triumph, sense of attainment and optimism regarding the organization. On the other hand, organizational and personal goals are aligned. External and internal motivation of employees is enhanced by some job and involvement of employees towards them (Akinbobola, 2011 \& Zandi \& Haseeb, 2019). 
Researchers mentioned that job involvement provides power to individuals to make decisions to strengthen the foundation of the organization. Level of employee's job involvement, commitment and motivation can be checked by the data of employees' retention. It is less likely that employees with a high level of job involvement, commitment and motivation will not leave the organization (Blau, 1985; Razzaq, 2014).

In the past, the top management did not give attention to the issues related to the turnover of the employees. Managers did not understand the way the productivity of the organization is impacted by the turnover of the employees. So, it is very significant to conduct research on turnover of employees because it will help in identifying the problems causing employees to switch their job (Al Mamun \& Hasan, 2017). The current study adds significant literature to the body of knowledge regarding these important variables of human resource. Study signifies that organizational commitment mediates the relationship between employee turnover and his job involvement.

The main purpose of the study is to look at the different causes creating the turnover among the employees of the organization. This study explores that strategies that enhance job involvement of employees must be implemented by the organizations, hence, to improve the organizational commitment of employees towards the particular organization. Thus, the employees will not voluntarily leave the organization, which will influence the overall organizational productivity.

\section{Literature Review}

\section{Turnover}

Turnover is attributed to outflow and inflow of the employee of an organization. Researchers consider this as one of the most important phenomena because managers are obligated by this to manage, comprehend, and capitalize on the consequences. Researchers defined turnover of employees working in an organization as opposite to retention. It is a relationship between the termination and admission related to the average amount of employees, independent of the reason and in a certain time period that causes flow (Ramalho Luz, Luiz de Paula, \& de Oliveira, 2018; Orji et al, 2018; Rahman, 2017; Riaz \& Riaz, 2018).

Employee turnover is the situation in which people working in the organization departs from their due to a number of reasons. Therefore, it negatively impacts the organization in terms of abilities and expenditure so that the minimum required services are distributed. When an employee leaves the job, it impacts the workforce and organization both. As the impact of turnover is very depressing, so scholars consider this topic of great importance (Yankeelov, Barbee, Sullivan, \& Antle, 2009).

One of the important impacts of turnover is an increment in the cost of training and recruitment of fresh employees. Businesses have to bear the cost to hire and interview the new candidate. Additionally, hiring a new employee who is skilled as well is very time taking and costly process because organizations must spend money to hire new employees, train them and make them productive for the organization. On the other hand, the concentration of experienced employees is diverted because they are responsible for training the new employee. All these activities will negatively impact the productivity, revenue and profitability of the organization. Additionally, the combined impact of all these effects leads to a decrease in the profit of the organization. Any business activity which leads to reduce the productivity or increase the cost impact the profitability of the organization.

The profit margin of business decrease as a result of an increase in turn over, which is evident from the example of Harvard business school. Most of the times, it takes business months to achieve the same amount of profitability. It is because un expected cost is increased for the business as a result of high turnover (Ton \& Huckman, 2008).

Therefore, it is critical for the business to develop and maintain a strategic advantage. This business can do be retaining the skilled, talented and hard-working employees. Therefore, it is important that business understand 
the importance of employee who is valuable. They must also identify an employee who does not contribute to the growth of the organization. This can be done by the organization by adopting various strategies in which a number of employees are involved in every function of the organization. By this way, commitment and motivation of employees are increased (Mak \& Sockel, 2001).

\section{Organizational Commitment}

Organizations are very much involved in the concept of organizational commitment since long. But still, it is a very important concept because of the changing dynamics of the industry. The demand for the skilled employee is rising due to the intense competition, so the skilled employee is invited in many organizations to join for the job. Whereas, it is very difficult for an organization to find skilled and qualified employees as the replacement in the organization. Therefore, organizational commitment is considered as one of the most important concepts. A number of different definitions are presented by a number of researchers to explain and define the concepts (Jain, Giga, \& Cooper, 2009:Mahmood et al., 2016).

Researchers considered organizational commitment as the psychological commitment or attachment of employee with the organization. Researchers mentioned that it shows the amount of which adopts or internalize the characteristics of an organization. Its also been defined as the force which binds the employee to certain actions required to achieve certain goals and objectives of the organization (Ruokolainen, 2011). Organizational commitment is defined by the scholars as having three characteristics including (1) strong desire in the organizational employee to maintain its membership (2) willingness of employee to put effort for the goals and objectives of organization (1) self-belief to accept the goals and objectives of organization (Enache, M. Sallán, Simo, \& Fernandez, 2013). On the other hand, according to the theory of Allen Meyer (1990), there are three different forms of commitment in the employee namely normative commitment, continuance commitment and affective commitment (García-Cabrera \& García-Soto, 2012).

The emotional involvement, identification and attachment of employee with the organization are known as affective commitment. The employees having strong affective commitment wants to stay in the organization because they want to stay (Allen \& Meyer, 1990). The commitment based on the amount of cost, which will be bearded by the employee if the employee leaves the organization. So, they want to stay in the organization because they do not have any other choice. In the end, under normative commitment, the employee is obligated to stay in the organization. In other words, the employee ought to stay in the organization, so he/ she stay in the organization (Norizan, 2012; Rosli \& Siong, 2018; Saad et al, 2018; Myambo \& Munyanyi, 2017).

\section{Job involvement}

Researchers have defined job involvement as the degree to which an employee wants to be committed or to be identified by the job assigned. The employees who are involved highly with their job wants to perform well and get good results. These people care a lot about their job, and they are also concerned about their tasks (Chughtai, 2008).

Despite that, the construct of organizational commitment and identification are the same, but these constructs differ as well. These constructs look the same because they are related to the identification of employee with the experience of work. Job involvement is basically the involvement of employee with its immediate activity of task. Therefore, there are a number of cases in which the employee is not committed to the organization but involved in the job (Singh \& Gupta, 2015).

Personal characteristics are involved in job involvement, including values, level of control, need strength, tenure, sex, education and age. Job characteristics are also involved like supervisory behavior, feedback, skill variety, task identity, task significance, and task autonomy. Researchers reported that personal and situational factors predict job involvement (Carmeli, 2005). 
Most of the researchers agree that employees who are involved in their job highly placed their job in the center of their all interests. On the other hand, the concentration of low level of involved employees is on the other things than their jobs. The employees who have a high level of job involvement are more self-confident and independent. Moreover, they perform their work according to the need of the organization (Chen \& Chiu, 2009).

Job involvement of employees is also highly affected by the work environment in which job is being performed. Its is because employee perceives ones work to be meaningful, can give feedback, maintain a clear set of norms, can control how to complete the task, can provide supportive relation to coworker and supervisor (Brown \& Leigh, 1996).

\section{Organizational Commitment and turnover}

An employee who is committed is motivated truly so it can meaningfully contribute to the success of the organization. Commitment is positively related to performance and work effort. Whereas, it is negatively related to turnover, workplace stress, intention to leave and absenteeism (Alexandrov, Babakus, \& Yavas, 2007; Nasr, 2012; Paré \& Tremblay, 2007; Ugboro, 2006; Vandenberghe, Bentein, \& Stinglhamber, 2004). Past studies upon the development and learning of organization found the link of organizational commitment with turnover as well. Its been reported that there exists a significant negative relationship between turnover and organizational commitment of employee (Joo \& Park, 2010).

\section{Job involvement and Organizational Commitment}

There exists a significant impact of job involvement on a number of organizational outcomes. It's been reported by a number of researchers that there exists positive significant impact of job involvement of professional and organizational commitment. As a result, the turnover, productivity sales, profit, stress, turnover intention and satisfaction are also impacted as well. (Kappagoda, 2013; Singh \& Gupta, 2015; Uygur, 2009).

It is because past studies have conceptualized job involvement as the active participation of one employee in his/ her job. It is also conceptualized as a degree of involvement of employee in its job, so that the intrinsic needs can be fulfilled. As these needs are fulfilled, satisfaction is achieved by the employee, as the result of the job, involvement employee can make a decision regarding his. Her job, which also strengthens job involvement (Zopiatis, Constanti, \& Theocharous, 2014). As a result, high job involvement brings a commitment to the employee towards its organization. So, the employee put a lot of effort to achieve organizational goals and objectives (Rotenberry \& Moberg, 2007).

Researchers pointed out that there exists a strong relationship between normative commitment and effective commitment and job involvement with lead to the continuance commitment (Kuruüzüm, Ipekçi Çetin, \& Irmak, 2009). According to scholars, normative and affective commitment has a strong relationship with the involvement of the job of the employee (Ketchand \& Strawser, 2001; Tayyeb \& Riaz, 2004).

\section{Job involvement and Turnover}

Its been observed by a number of researchers that attitudinal variables like job satisfaction, job involvement and organizational outcomes are the outcomes of HR practices of the HR department of the organization. The HR practices of the organization decide that an individual will stay or leave the organization, causing the turnover (Biswas, 2008).

Researchers have found that all three approaches of organizational commitment, namely institutional, normative and affective have a negative impact on the turnover of the employee. It is because the possibility of turnover is decreased due to commitment. The main reason is that such an employee is motivated and committed to working for the organization (Ramalho Luz et al., 2018). 
Studies find that job involvement had a negative and significant effect on employee's outgoing intent and job involvement is able to fabricate good teamwork among employees. The preceding statement is in line with other studies, which finds that high employee involvement proved effective to increase job satisfaction and able to discourage employee turnover intention (Alshammari et al., 2016). Job involvement in practice relates to absenteeism, the degree of application to stop working and wishes to participate in a team or working group. Moreover, unnoticed job involvement level would result in employees' absence and high turnover intention (Hairiah \& Faslah, 2017).

Research Framework is presented below (Figure 1).

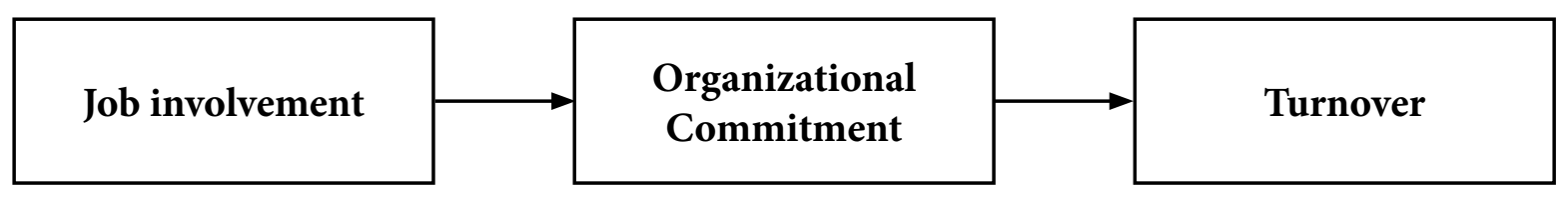

Figure 1. Research framework

The preceding framework has led to hypothesize the following research hypotheses:

$\mathrm{H} 1$ : the job involvement is in a significant relationship with the turnover.

$\mathrm{H} 2$ : The job involvement is in a significant relationship with organizational commitment.

H3: The organizational commitment is in a significant relationship with the turnover.

H4: Organizational commitment mediates the relationship between job involvement and turnover.

\section{Research Methodology}

The original questionnaire was worded in English, but since the targeted study respondents 'mother tongue, it was translated into language following the recommendations by (Brislin, 1970). The translation was carried out through back translation procedure, where the questionnaire was translated into English in order to confirm both validity and reliability of the wording. The two English versions of the questionnaire were then compared after which minor changes were made accordingly. Back translation guarantees the near equivalence of the two English versions of the questionnaire. Data analysis in this study was conducted with the help of the software package, Smart PLS, Version 2.0 M3, as suggested by (Ringle, Wende, \& Will, 2005). Smart PLS is extensively utilized in the field of marketing and management science (Reinartz, Haenlein, \& Henseler, 2009).

According to researchers, a PLS model is generally analyzed and interpreted in two phases; first measuring the outer model for validity and reliability and second, analyzing the structure model by R square, effect size, predictive model relevance, and goodness of fit (GOF) (Hair, Ringle, \& Sarstedt, 2011). In the first phase, properties of multi-item constructs are measured with the inclusion of convergent validity and discriminant validity. Following the second phase, the study hypotheses testing is conducted through the bootstrapping method. The initial study model comprised reflective measurement items that are manifest variables or indicators, four latent variables including two independent, one dependent variable and one mediating variable constituting 16 relationships between them on the basis of the proposed study.

\section{Results}

Many contemporary studies have viewed SEM not only as a statistical procedure but also as a process which involves few stages: (1) conceptualizing the model (2) parameter identification (3) model specification (4) estimation of model (5) modification of model and (6) evaluation of parameters (Hameed, Basheer, Iqbal, Anwar, \& Ahmad, 2018; Hancock \& Mueller, 2007). These steps are necessary when carrying out SEM analysis (Hameed et al., 2018). They are hereby explained in succession. The first stage of any SEM analysis should be for the researcher to conceptualize the model, this entails pointing out which relationships are hypothesized to exist among observed and latent variables (Figure 2). 


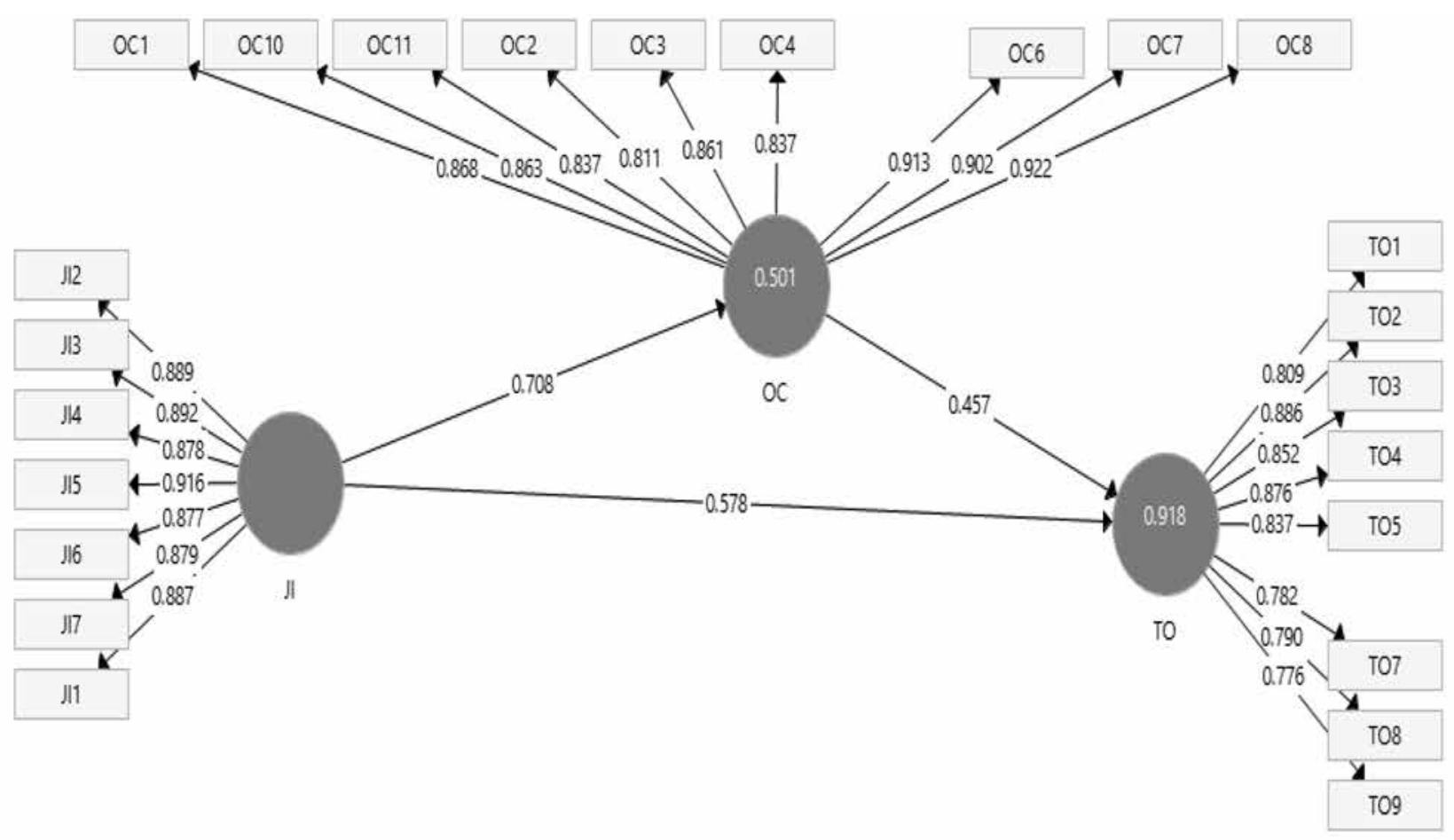

Figure 2. Measurement Model

The theoretical model is based on the underlying theory that gave rise to the variables being investigated and should be focused on literature and knowledge on the subject matter. Ideally, in SEM applications, the operationalized theories assume the form of the measured variable path analysis model, that is hypothesized structural or causal relationships among variables that are directly measured (Hancock \& Mueller, 2004). Before testing of hypotheses, the partial Least Square-Structural Equation Modeling is employed to analyze the outer model (Table 1). A method was followed to assess the model as by (Basheer, Siam, Awn, \& Hassan, 2019).

Table 1. Outer Loading

\begin{tabular}{|c|c|c|c|}
\hline & JI & OC & TO \\
\hline JI1 & 0.887 & & \\
\hline JI2 & 0.889 & & \\
\hline JI3 & 0.892 & & \\
\hline JI4 & 0.878 & & \\
\hline JI5 & 0.916 & & \\
\hline JI6 & $\mathbf{0 . 8 7 7}$ & & \\
\hline JI7 & 0.879 & & \\
\hline OC1 & & 0.868 & \\
\hline OC10 & & 0.863 & \\
\hline OC11 & & $\mathbf{0 . 8 3 7}$ & \\
\hline OC2 & & 0.811 & \\
\hline OC3 & & 0.861 & \\
\hline OC4 & & $\mathbf{0 . 8 3 7}$ & \\
\hline OC6 & & 0.913 & \\
\hline OC7 & & 0.902 & \\
\hline OC8 & & 0.922 & \\
\hline TO1 & & & 0.809 \\
\hline TO2 & & & 0.886 \\
\hline
\end{tabular}




\begin{tabular}{|c|c|c|c|}
\hline TO3 & & & 0.852 \\
\hline TO4 & & & 0.876 \\
\hline TO5 & & & 0.837 \\
\hline TO7 & & & 0.782 \\
\hline TO8 & & & 0.790 \\
\hline TO9 & & & 0.776 \\
\hline
\end{tabular}

According to Hair et al. (2010), convergent validity is the extent to which a set of variables intersect to estimate a particular concept. Analyzing the convergent validity requires the simultaneous testing of three criteria, i.e. composite reliability, factor loading, and the average variance extracted. Firstly, the assessment of loadings for all items indicated that all factor loadings are above 0.5 , with a significance level of 0.01 percent, showing an acceptable level according to the literature. Secondly, the composite reliability is tested, which refers to the extent to which a group of items invariably explains the latent variables. The table 2 contains the values for composite reliability and Cronbach Alpha. The range of Cronbach alpha came out to be $0.890-0.964$, and range of composite reliability was $0.759-0.971$, which was higher than the recommended range (Fornell \& Larcker, 1981), i.e. 0.7. The results proclaimed and confirmed the convergent validity. Furthermore, the AVE is also obtained for the outer model in order to assess the convergent validity. It explains the average variance extracted for a set of items in comparison with the shared variance, involving measurement errors. In addition, it determines the variance that the indicators cover in comparison with the variance which is assigned with the measurement errors. Thus, according to several studies if the value of the average value extracted reaches the level of 0.5 , then it indicates the adequate convergence of this group of items to determine the required construct. The range of AVE for the present study came out as $0.510-0.919$, exhibiting a good validity of the measures.

Table 2. Reliability

\begin{tabular}{|c|c|c|c|c|}
\hline & Cronbach's Alpha & rho_A & Composite Reliability & $\begin{array}{c}\text { Average Variance } \\
\text { Extracted (AVE) }\end{array}$ \\
\hline IAS & 0.924 & 0.927 & 0.983 & 0.755 \\
\hline PI & 0.812 & 0.834 & 0.864 & 0.861 \\
\hline SA & 0.940 & 0.944 & 0.994 & 0.878 \\
\hline
\end{tabular}

Developing a discriminant validity is essential to declare the construct validity for the outer model. Therefore, testing of discriminant validity is crucial before the hypotheses testing. A discriminant validity measures the level to which the items of the model differentiate from their constructs. Similarly, the discriminant validity indicated that a number of items had employed different constructs that exhibited no overlapping. Moreover, according to the research, the shared variance of the measures that exist among each construct must be higher than the shared variance between the different constructs (Compeau, Higgins, \& Huff, 1999). The square root of the average variance extracted was then replaced for all the constructs with diagonal elements of the correlation matrix, as mentioned in the table. The diagonal elements of the matrix turned out to be greater than the elements of rows and columns, thus, verifying the discriminant validity (Table 3).

Table 3. Discriminant Validity

\begin{tabular}{|c|c|c|c|}
\hline & JO & OC & TO \\
\hline JI & $\mathbf{0 . 8 0 9}$ & & $\mathbf{0 . 7 7 6}$ \\
\hline OC & 0.592 & 0.620 & $\mathbf{0 . 8 2 4}$ \\
\hline TO & 0.673 & & \\
\hline
\end{tabular}

In light of the measurement of construct validity for the outer model, therefore it is assumed that the results of hypotheses testing must be valid and highly reliable. After the goodness of fit test for the outer model, the hypotheses were tested to assess the nature of the association between the variables. The hypotheses testing for the present study is made through PLS Algorithm, employing smart PLS technique (Table 4). 
Table 4. Direct relations

\begin{tabular}{|c|c|c|c|c|c|}
\hline & $\begin{array}{c}\text { Original Sample } \\
(\mathbf{O})\end{array}$ & Sample Mean (M) & $\begin{array}{c}\text { Standard Deviation } \\
(\text { STDEV) }\end{array}$ & $\begin{array}{c}\text { T Statistics } \\
(\mid \mathbf{O} / \text { STDEV } \mid)\end{array}$ & P Values \\
\hline JI -> TO & 0.038 & 0.028 & 0.017 & 3.918 & $\mathbf{0 . 0 0 0}$ \\
\hline JI -> OC & 0.032 & 0.032 & 0.026 & 4.527 & $\mathbf{0 . 0 0 0}$ \\
\hline OC -> TO & 0.045 & 0.045 & 0.010 & 4.294 & $\mathbf{0 . 0 0 0}$ \\
\hline
\end{tabular}

The mediation effect is shown in table 5 .

Table 5. Indirect results

\begin{tabular}{|c|c|c|c|c|c|}
\hline & $\begin{array}{c}\text { Original Sample } \\
(\mathbf{O})\end{array}$ & $\begin{array}{c}\text { Sample Mean } \\
(\mathbf{M})\end{array}$ & $\begin{array}{c}\text { Standard Deviation } \\
(\text { STDEV })\end{array}$ & $\begin{array}{c}\text { T Statistics } \\
(\mid \mathbf{O} / \text { STDEV } \mid)\end{array}$ & P Values \\
\hline JI $>$ OC $>$ TO & 0.028 & 0.028 & 0.007 & 3.918 & $\mathbf{0 . 0 0 0}$ \\
\hline
\end{tabular}

Under multivariate analysis, the coefficient of determination shows that the predictor variables explain the endogenous variable. Thus, the magnitude of $\mathrm{R}^{2}$ explains the predictive power of explaining the endogenous variable in the model.

Table 6. R-Square

\begin{tabular}{|c|c|}
\hline & R Square \\
\hline OC & 0.501 \\
\hline TO & 0.918 \\
\hline
\end{tabular}

Furthermore, following (Geisser, 1975), the sample was reapplied in order to declare the models' predictive validity. Partial Least Square technique is used as it is an appropriate and very well software for reusing the sampling technique (Table 6).

\section{Conclusion}

Meanwhile, the study has examined the mediating role of organizational commitment in the relationship between job involvement and turnover. The study broached an argument that in the era of globalization, it has been regarded to be a key issue to deal with employee turnover for any business organization. To date, agreement on how to practice this concept has not yet been resolved. Employing the survey-based methodology, the SEM-PLS technique is used to test the hypothesized relationships. So, the current study has used SEM-PLS as a statistical tool to answer the research questions raised in this study and research objectives envisaged in the current study. The data is collected from the managers of the manufacturing firms in Indonesia. The findings of the study have provided support to the theoretical foundation and the proposed hypothesis of the current study. The current study will be helpful for policymakers and practitioners in understanding the issues related to job involvement, turnover, and organizational commitment. In author knowledge, this is among very few pioneering studies on this issue. the combined effect of the negatives can result from high turnover, leading a firm to generate less profit. Anything that leads to increase costs or reduce productivity, income will tend to reduce profit. Studies find that job involvement had a negative and significant effect on employee's outgoing intent and job involvement is able to fabricate good teamwork among employees. The findings are in line with (Alshammari et al., 2016), who finds that high employee involvement proved effective to increase job satisfaction and able to discourage employee turnover intention. Job involvement in practice relates to absenteeism, the degree of application to stop working and wishes to participate in a team or working group. Moreover, unnoticed job involvement level would result in employees' absence and high turnover intention. Evidence for this is provided by the Harvard Business School; when businesses experience higher turnover, they will get lower profit margins. It often takes months or years for a new business to achieve profitability due to the increase of unexpected costs as high turnover and needs to start a new venture to make a profit. 


\section{References}

Abdallah, A. B., Obeidat, B. Y., Aqqad, N. O., Al Janini, M., \& Dahiyat, S. E. (2017). An integrated model of job involvement, job satisfaction and organizational commitment: a structural analysis in Jordan's banking sector. Communications and Network, 9(1), 28-53. Available at: https://doi.org/10.4236/cn.2017.91002

Ahmed, M., \& Nawaz, N. (2015). Impact of organizational commitment on employee turnover: A case study of Pakistan International Airlines (PIA). Industrial Engineering Letters Journal, 5(8).

Akinbobola, O. (2011). Conflict in human capital relationships: The impact of job satisfaction on job involvement in a workplace. International Journal of Social Science and Humanity, 1(2), 92. Available at: https://doi.org/10.7763/ijssh.2011.v1.16

Al Mamun, C. A., \& Hasan, M. N. (2017). Factors affecting employee turnover and sound retention strategies in business organization: A conceptual view. Problems and Perspectives in Management, 15(1), 63-71. Available at: https://doi.org/10.21511/ppm.15(1).2017.06

Alexandrov, A., Babakus, E., \& Yavas, U. (2007). The effects of perceived management concern for frontline employees and customers on turnover intentions: moderating role of employment status. Journal of service research, 9(4), 356-371. Available at: https://doi. org/10.1177/1094670507299378

Allen, N. J., \& Meyer, J. P. (1990). The measurement and antecedents of affective, continuance and normative commitment to the organization. Journal of occupational psychology, 63(1), 1-18. Available at: https://doi.org/10.1111/j.2044-8325.1990.tb00506.x

Alshammari, M. A., Qaied, B. A. A., Al-Mawali, H., \& Matalqa, M. (2016). What Drives Employee's Involvement and Turnover Intentions: Empirical Investigation of Factors Influencing Employee Involvement and Turnover Intentions? International Review of Management and Marketing, 6(2), 298-306.

Anttila, E. (2015). Components of organizational commitment-A case study consisting managers from Finnish industrial company.

Basheer, M., Siam, M., Awn, A., \& Hassan, S. (2019). Exploring the role of TQM and supply chain practices for firm supply performance in the presence of information technology capabilities and supply chain technology adoption: A case of textile firms in Pakistan. Uncertain Supply Chain Management, 7(2), 275-288. Available at: https://doi.org/10.5267/j.uscm.2018.9.001

Bernardi, A. (2019). The capability approach and organizational climate as tools to study occupational health and safety. Insights into Regional Development, 1(2), 155-16

Biswas, S. (2008). Job Involvement as a Predictor of Turnover Intention. LBS Journal of Management \& Research, 6(1and2), 32-37.

Blau, G. J. (1985). A multiple study investigation of the dimensionality of job involvement. Journal of vocational behavior, $27(1)$, 19-36. Available at: https://doi.org/10.1016/0001-8791(85)90050-8

Bonds, A. A. (2017). Employees’ Organizational Commitment and Turnover Intentions.

Brislin, R. W. (1970). Back-translation for cross-cultural research. Journal of cross-cultural psychology, 1(3), 185-216. Available at: https://doi.org/10.1177/135910457000100301 https://doi.org/10.1177/135910457000100301

Brown, S. P., \& Leigh, T. W. (1996). A new look at psychological climate and its relationship to job involvement, effort, and performance. Journal of applied psychology, 81(4), 358. Available at: https://doi.org/10.1037//0021-9010.81.4.358

Carmeli, A. (2005). Exploring determinants of job involvement: An empirical test among senior executives. International Journal of Manpower, 26(5), 457-472. Available at: https://doi.org/10.1108/01437720510615143

Chen, C.-C., \& Chiu, S.-F. (2009). The mediating role of job involvement in the relationship between job characteristics and organizational citizenship behavior. The Journal of social psychology, 149(4), 474-494. Available at: https://doi.org/10.3200/socp.149.4.474-494

Chughtai, A. A. (2008). Impact of job involvement on in-role job performance and organizational citizenship behaviour. Journal of Behavioral \& Applied Management, 9(2).

Compeau, D., Higgins, C. A., \& Huff, S. (1999). Social cognitive theory and individual reactions to computing technology: A longitudinal study. MIS quarterly, 145-158. Available at: https://doi.org/10.2307/249749_

Dahiyat, S. E. (2015). An integrated model of knowledge acquisition and innovation: examining the mediation effects of knowledge integration and knowledge application. International Journal of Learning and change, 8(2), 101-135. Available at: https://doi.org/10.1504/ ijlc.2015.074064 
Enache, M., M. Sallán, J., Simo, P., \& Fernandez, V. (2013). Organizational commitment within a contemporary career context. International Journal of Manpower, 34(8), 880-898. Available at: https://doi.org/10.1108/ijm-07-2013-0174

Fornell, C., \& Larcker, D. F. (1981). Structural equation models with unobservable variables and measurement error: Algebra and statistics: SAGE Publications Sage CA: Los Angeles, CA.

García-Cabrera, A. M., \& García-Soto, M. G. (2012). Organizational commitment in MNC subsidiary top managers: antecedents and consequences. The International Journal of Human Resource Management, 23(15), 3151-3177. Available at: https://doi.org/10.1080/09 585192.2011 .637057

Geisser, S. (1975). The predictive sample reuse method with applications. Journal of the American statistical Association, 70(350), 320328. Available at: https://doi.org/10.2307/2285815

Hair, J. F., Ringle, C. M., \& Sarstedt, M. (2011). PLS-SEM: Indeed a silver bullet. Journal of Marketing theory and Practice, 19(2), 139152. Available at: https://doi.org/10.2753/mtp1069-6679190202_

Hairiah, L., \& Faslah, R. (2017). The Influence Of Job Involvement and Job Satisfaction Toward Turnover Intention on Employees Of PT. Global Nikel Multiguna Tangerang. Jurnal Ilmiah Econosains, 15(1), 144-167. Available at: https://doi.org/10.21009/econosains.0151.09

Hameed, W. U., Basheer, M. F., Iqbal, J., Anwar, A., \& Ahmad, H. K. (2018). Determinants of Firm's open innovation performance and the role of R \& D department: an empirical evidence from Malaysian SME's. Journal of Global Entrepreneurship Research, 8(1), 29. Available at: https://doi.org/10.1186/s40497-018-0112-8

Hancock, G., \& Mueller, R. (2007). Structural equation modeling [lecture notes for EDMS 722: Structural Equation Modeling]. University of Maryland, College Park.

Hussain, H.I., Abidin, I.S.Z., Ali., A. \& Kamarudin, F. (2018) Debt Maturity and Family Related Directors: Evidence from a Developing Market, Polish Journal of Management Studies, 18 (2), 118 - 134.

Jain, A. K., Giga, S. I., \& Cooper, C. L. (2009). Employee wellbeing, control and organizational commitment. Leadership \& Organization Development Journal, 30(3), 256-273. Available at: https://doi.org/10.1108/01437730910949535

Joo, B.-K., \& Park, S. (2010). Career satisfaction, organizational commitment, and turnover intention: The effects of goal orientation, organizational learning culture and developmental feedback. Leadership \& Organization Development Journal, 31(6), 482-500. Available at: https://doi.org/10.1108/01437731011069999

Kappagoda, S. (2013). Job involvement as a mediator of the relationship between organizational commitment and job performance in the systemically important banks in Sri Lanka.

Ketchand, A. A., \& Strawser, J. R. (2001). Multiple dimensions of organizational commitment: Implications for future accounting research. Behavioral Research in Accounting, 13(1), 221-251. Available at: https://doi.org/10.2308/bria.2001.13.1.221

Kuruüzüm, A., Ipekçi Çetin, E., \& Irmak, S. (2009). Path analysis of organizational commitment, job involvement and job satisfaction in Turkish hospitality industry. Tourism review, 64(1), 4-16. Available at: https://doi.org/10.1108/16605370910948821

Lorincová, S., Hitka, M., Bajzíková, L., Weberová, D. (2019). Are the motivational preferences of employees working in small enterprises in Slovakia changing in time. Entrepreneurship and Sustainability Issues, 6(4), 1618-1635. https://doi.org/10.9770/jesi.2019.6.4(5)

Mahmood, A., Hussan, S. G., Sarfraz, M., Abdullah, M. I., \& Basheer, M. F. (2016). Rewards satisfaction, perception about social status and commitment of nurses in Pakistan. European Online Journal of Natural and Social Sciences, 5(4), 1049-1061.

Mak, B. L., \& Sockel, H. (2001). A confirmatory factor analysis of IS employee motivation and retention. Information \& management, 38(5), 265-276. Available at: https://doi.org/10.1016/s0378-7206(00)00055-0_

Myambo, A., \& Munyanyi, T. (2017). Fiscal Operations and Macroeconomic Growth: The Nigerian Experience. International Journal of Social and Administrative Sciences, 2(1), 31-44.

Nasr, L. (2012). The relationship between the three components model of commitment, workplace stress and career path application to employees in medium size organizations in Lebanon. Journal of Organizational Culture, Communications and Conflict, $16(1), 71$.

Norizan, I. (2012). Organizational commitment and job satisfaction among staff of higher learning education institutions in Kelantan. Universiti Utara Malaysia.

Orji, A., Ogbuabor, J. E., \& Anthony-Orji, O. I. (2018). Macroeconomic Indicators and Capital Formation Growth in Nigeria: A New Evidence. Journal of Social Economics Research, 5(2), 39-50. 
Orji, A., Ogbuabor, J. E., Okon, A. N., \& Anthony-Orji, O. I. (2018). Electronic Banking Innovations and Selected Banks Performance in Nigeria. The Economics and Finance Letters, 5(2), 46-57.

Paré, G., \& Tremblay, M. (2007). The influence of high-involvement human resources practices, procedural justice, organizational commitment, and citizenship behaviors on information technology professionals' turnover intentions. Group \& Organization Management, 32(3), 326-357. Available at: https://doi.org/10.1177/1059601106286875

Perera, C. R., Johnson, L. W., \& Hewege, C. R. (2018). A review of organic food consumption from a sustainability perspective and future research directions. International Journal of Management and Sustainability, 7(4), 204-214.

Pratama, H., \& Meutia, I. (2018). Financial Condition, Growth, Audit Quality and Going Concern Opinion: Study on Manufacturing Companies Listed on Indonesia Stock Exchange. Journal of Accounting, Business and Finance Research, 2(1), 16-25.

Rahati, A., Sotudeh-Arani, H., Adib-Hajbaghery, M., \& Rostami, M. (2015). Job involvement and organizational commitment of employees of prehospital emergency medical system. Nursing and midwifery studies, 4(4).

Ramalho Luz, C. M. D., Luiz de Paula, S., \& de Oliveira, L. M. B. (2018). Organizational commitment, job satisfaction and their possible influences on intent to turnover. Revista de Gestão, 25(1), 84-101. Available at: https://doi.org/10.1108/rege-12-2017-008

Razzaq, A. (2014). Impact of Job Involvement, Commitment, Job Satisfaction on Turnover: An Empirical Investigation on Banking Sector. Developing Country Studies, 4(2).

Reinartz, W., Haenlein, M., \& Henseler, J. (2009). An empirical comparison of the efficacy of covariance-based and variance-based SEM. International Journal of research in Marketing, 26(4), 332-344. Available at: https://doi.org/10.1016/j.ijresmar.2009.08.001

Ringle, C. M., Wende, S., \& Will, S. (2005). SmartPLS 2.0 (M3) Beta, Hamburg 2005.

Rahman, W. A. W. A. (2017). Transformational Leadership and Empathy: The Impact of Quality in the Health Care Services in Kelantan, Malaysia. International Journal of Economics, Business and Management Studies, 4(1), 50-56.

Riaz, N., \& Riaz, S. (2018). Investment and Economic Growth: A Panel Data Analysis. Asian Development Policy Review, 6(1), $20-31$.

Rosli, A., \& Siong, T. I. (2018). Determinants of Customers Satisfaction Towards Services Provided by Agencies in Urban Transformation Centre (UTC). International Journal of Economics, Business and Management Studies, 5(1), 9-15.

Rotenberry, P. F., \& Moberg, P. J. (2007). Assessing the impact of job involvement on performance. Management research news, 30(3), 203-215. Available at: https://doi.org/10.1108/01409170710733278

Ruokolainen, M. (2011). Do organizational and job-related factors relate to organizational commitment?: A mixed method study of the associations. Jyväskylä Studies in education, psychology and social research(428).

Singh, A., \& Gupta, B. (2015). Job involvement, organizational commitment, professional commitment, and team commitment: A study of generational diversity. Benchmarking: An International Journal, 22(6), 1192-1211. Available at: https://doi.org/10.1108/bij-01-20140007

Saad, S., Umer, I., \& Ahmed, F. (2018). An empirical evidence of over reaction hypothesis on karachi stock exchange (KSE). Asian Economic and Financial Review, 8(4), 449-465.

Tayyeb, S., \& Riaz, M. N. (2004). Validation of the three-component model of organizational commitment in Pakistan. Pakistan Journal of Psychological Research, 19(3-4).

Ton, Z., \& Huckman, R. S. (2008). Managing the impact of employee turnover on performance: The role of process conformance. Organization science, 19(1), 56-68. Available at: https://doi.org/10.1287/orsc.1070.0294

Ugboro, I. O. (2006). Organizational commitment, job redesign, employee empowerment and intent to quit among survivors of restructuring and downsizing. Journal of Behavioral \& Applied Management, 7(3).

Uygur, A. (2009). A study into organizational commitment and job involvement: An application towards the personnel in the central organization for Ministry of Health in Turkey. Ozean Journal of Applied Science; 2(1).

Vandenberghe, C., Bentein, K., \& Stinglhamber, F. (2004). Affective commitment to the organization, supervisor, and work group: Antecedents and outcomes. Journal of vocational behavior, 64(1), 47-71. Available at: https://doi.org/10.1016/s0001-8791(03)00029-0

Wynen, J., Van Dooren, W., Mattijs, J., \& Deschamps, C. (2019). Linking turnover to organizational performance: The role of process conformance. Public Management Review, 21(5), 669-685. Available at: https://doi.org/10.1080/14719037.2018.1503704 
Yankeelov, P. A., Barbee, A. P., Sullivan, D., \& Antle, B. F. (2009). Individual and organizational factors in job retention in Kentucky's child welfare agency. Children and Youth Services Review, 31(5), 547-554. Available at: https://doi.org/10.1016/j.childyouth.2008.10.014

Yin-Fah, B. C., Foon, Y. S., Chee-Leong, L., \& Osman, S. (2010). An exploratory study on turnover intention among private sector employees. International journal of business and management, 5(8), 57. Available at: https://doi.org/10.5539/ijbm.v5n8p57

Yücel, İ. (2012). Examining the relationships among job satisfaction, organizational commitment, and turnover intention: An empirical study. International journal of business and management, 7(20), 44. Available at: https://doi.org/10.5539/ijbm.v7n20p44

Zandi, G., \& Haseeb, M. (2019). The role of trade liberalization in carbon dioxide emission: Evidence from heterogeneous panel estimations. International Journal of Financial Research, 10 (5), 228-240.

Zopiatis, A., Constanti, P., \& Theocharous, A. L. (2014). Job involvement, commitment, satisfaction and turnover: Evidence from hotel employees in Cyprus. Tourism Management, 41, 129-140. Available at: https://doi.org/10.1016/j.tourman.2013.09.013

Slamet WIDODO is the Associate Professor of Human Resources and Strategic Management at Departement of Management in Economic and Business Faculty, University of Bengkulu. Research interests: Human Resources Management, Strategic Management, SME, and Public Sector Management.

ORCID:org/0000-0002-7277-1811

Marlina WIDIYANTI is the Associate Professor of Financial Management and Strategic Management at Departement of Management in Economic Faculty, University of Sriwijaya. Research interests: Finance Management, Strategic Management, Banking Syariah Management, Human Resources, Marketing Management and Public Sector Management.

ORCID: org/0000-0003-0431-814x

Tetra HIDAYATI is a Doctor in the field of human resource management and coordinator of the Master of Management study program. Interest in research in the field of human resource management. Currently as the most active lecturer in the management department, University of Mulawarman in Samarinda Indonesia

ORCID:org/0000-0003-2753-0573

WIYADI is the Associate Professor of Marketing Management and Financial Management at Master of Management in Economic and Business Faculty, Universitas Muhammadiyah Surakarta. Research interests: Marketing Management, Consumer Behaviour, Financial Management, and Human Resources Management.

ORCID: org/0000-0002-9470-3748

Nelson SITUMORANG is a Student program Ph.D and The Candidate Doctor of Human Resources and Strategic Management at Departement of Management in Economic and Business Faculty, University of Bengkulu. Research interest : Human Resources Management and Public Sector Management.

ORCID: org/0000-0001-5362-1706

This work is licensed under the Creative Commons Attribution International License (CC BY). http://creativecommons.org/licenses/by/4.0/ 